\title{
EFFECT OF NITROGEN ON WEED INFESTATION AND PERFORMANCE OF BORO RICE UNDER TWO SELECTED HERBICIDES
}

\author{
M. M. Morshed ${ }^{1}$, M. N. Bari ${ }^{1}$, Q. A. Khaliq ${ }^{1}$ and M. S. Alam ${ }^{2}$ \\ ${ }^{1}$ Department of Agronomy, Bangabandhu Sheikh Mujibur Rahman Agricultural University, Gazipur-1706 \\ ${ }^{2}$ Department of Soil Science, Bangabandhu Sheikh Mujibur Rahman Agricultural University, Gazipur-1706 \\ Corresponding Author: manjur.morshed69@gmail.com
}

\begin{abstract}
A field experiment was conducted at the experimental farm of Bangabandhu Sheikh Mujibur Rahman Agricultural University (BSMRAU), Salna, Gazipur from November 2013 to May 2014 to determine the effect of nitrogen and herbicide on weed infestation and performance of Boro rice (cv. BRRIdhan28). Five nitrogen doses i.e. 0 , 50.6 , 101.2 , 151.8 and $202.4 \mathrm{~kg}$ $\mathrm{ha}^{-1}$ under selected pre-emergence and post-emergence herbicides along with one weed free and control (unweeded) treatment were imposed in the experiment. Nine weed species was found to dominate in the experimental plots where Scirpus maritimus L. showed the maximum visual abundance (58\%) followed by Leersia hexandra sw., Paspalam distichum L. and Fimbristylis miliacea L. Post-emergence herbicide contributed to higher control efficiency than that in pre-emergence herbicide. Post-emergence herbicide without receiving nitrogen showed the highest weed control efficiency (97.39) at 60 days after transplanting. Treatment receiving N @ $200.4 \mathrm{~kg} \mathrm{ha}^{-1}$ under post-emergence herbicide showed the highest number of tiller per hill (13.00), total dry matter $\left(1568.6 \mathrm{~g} \mathrm{~m}^{-2}\right)$, panicles per hill (10.60), filled grains per panicle (125.20) and grain yield (6.46 t/ha). N-dose $151.8 \mathrm{~kg} \mathrm{ha}^{-1}$ under postemergence herbicide contributed to the second highest grain yield $\left(6.41 \mathrm{t} \mathrm{ha}^{-1}\right)$ with the highest benefit cost ratio of 1.60 but $50.6 \mathrm{~kg} \mathrm{~N} \mathrm{ha}^{-1}$ under post-emergence herbicide showed the maximum Nitrogen use efficiency of 0.49 . The study revealed that nitrogen dose up to $151.8 \mathrm{~kg} \mathrm{ha}^{-1}$ might be increased above the recommended dose under coverage of a suitable post-emergence herbicide for profitable rice production.
\end{abstract}

\section{Introduction}

The area and production of total rice in Bangladesh is about 11.35 million hectares and $31.98 \mathrm{mMT}$, respectively where Boro rice contributes to the production of $18.06 \mathrm{mMT}$. However, the average yield of rice is low (4.34 t ha ${ }^{-1}$ ) in Bangladesh (BRRI, 2011) compared to other rice growing countries. Weed is one of the most important pests causing reduction of grain yield by 70-80\% in Aus rice, 30$40 \%$ transplanted Aman rice and 22-36\% in Boro rice (BRRI, 2009). Hence, proper weed management practices are essential to obtain better yields in transplanted rice. In Bangladesh, the traditional methods of weed control practices involve huge labour and at the same time it is tedious, time consuming and expensive. A wide range of pre and post emergence herbicides such as Butachlor, Pretilachlor, Oxadiazone, Pyrazosulfuron-Ethyl, Ethoxysulfuron either alone or supplemented with hand weeding have been found to be useful for weed management in transplanted paddy (Mamun, 2011). Nitrogen is a major essential plant nutrient and key input for increasing crop yield (Dastan et al., 2012). However, both weed and rice plants compete for nitrogen and in a weed infested field weeds uptake $\mathrm{N}$ more rapidly than rice plant, particularly at high nitrogen levels (Nyarko and De Datta., 1993). It was found that, growth and seed production of E. crussgalli increases with increases in nitrogen rate resulting lesser nitrogen availability to the rice plants (Chauhan and Abugho, 2013). Therefore, proper herbicide and dose of nitrogen fertilizer are both critical factors for efficacy in weed management as well as growth and productivity of rice. Effects of these two factorial effects were observed individually on rice but information on the combined effect of weed control and nitrogen dose on weed infestation behavior and productivity of transplanted wetland rice are scanty under 
Morshed et al.

Bangladesh context. With this consideration, the present study was undertaken to determine the effect of nitrogen on weed infestation behavior, to evaluate the growth and yield of Boro rice as well as to find out suitable combination of dose of nitrogen and herbicide for effective weed management and productivity of Boro rice.

\section{Materials and Methods}

A field experiment was conducted at the experimental farm of the Bangabandhu Sheikh Mujibur Rahman Agricultural University, Salna, Gazipur under wet land condition from November to May, 2013-2014. The soil of the experimental site was silty clay of Shallow Red Brown Terrace type under Salna Series of Madhupur Tract in the Agro Ecological Zone (AEZ) 28. The experimental site is situated in a sub-tropical climatic zone, characterized by heavy rainfall during the months from May to September and scanty rainfall during rest of the year. Boro rice variety BRRIdhan 28 was used as test crop. Two herbicides; Pretilachlor (pre-emergence at 5 DAT) \& Pyrazosulfuran-Ethyl (postemergence at $15 \mathrm{DAT}$ ) were used in the experiment. There are 12 treatments such as $\mathrm{T}_{1}=$ Pretilachlor @1L ha ${ }^{-1}+$ Nitrogen@0 kg ha ${ }^{-1}, \mathrm{~T}_{2}=$ Pretilachlor@ $@ 1 \mathrm{~L} \mathrm{ha}{ }^{-1}+$ Nitrogen @ $50.6 \mathrm{~kg} \mathrm{ha}{ }^{-1}, \mathrm{~T}_{3}=$ Pretilachlor @ 1L ha ${ }^{-1}+$ Nitrogen @ 101.2 kg ha $\left.{ }^{-1}\right), \mathrm{T}_{4}=$ Pretilachlor @ 1L ha ${ }^{-1}+$ Nitrogen @ 151.8 $\left.\mathrm{kg} \mathrm{ha}^{-1}\right), \mathrm{T}_{5}=$ Pretilachlor@1L ha ${ }^{-1}+$ Nitrogen @ $202.4 \mathrm{~kg} \mathrm{ha}^{-1}, \mathrm{~T}_{6}=$ Pyrazosulfuron-ethyl @ 150g $\mathrm{ha}^{-1}+$ Nitrogen@0 kg ha ${ }^{-1}, \mathrm{~T}_{7}=$ Pyrazosulfuron-ethyl @ $150 \mathrm{~g} \mathrm{ha}^{-1}+$ Nitrogen @ $50.6 \mathrm{~kg} \mathrm{ha}^{-1}, \mathrm{~T}_{8}=$ Pyrazosulfuron-ethyl @ 150g ha ${ }^{-1}+$ Nitrogen @ $101.2 \mathrm{~kg} \mathrm{ha}^{-1}, \mathrm{~T}_{9}=$ Pyrazosulfuron-ethyl @ 150g ha ${ }^{-1}$ + Nitrogen@151.8 kg ha ${ }^{-1}, \mathrm{~T}_{10}=$ Pyrazosulfuron-ethyl @ 150g ha ${ }^{-1}+$ Nitrogen @ $202.4 \mathrm{~kg} \mathrm{ha}^{-1}, \mathrm{~T}_{11}=$ Control (Unweeded + without nitrogen), $\mathrm{T}_{12}=$ Weed free (with recommended dose of $\mathrm{N}$ ). The experiment was laid out in a randomized complete block design (RCBD) with three replications. A fertilizer dose of 77-80-55-5 kg of Triple Super Phosphate, Muriate of Potash, Gypsum and Zinc sulfate respectively was applied in the experimental field (BRRI, 1999). The whole amount of fertilizers was applied as basal dose during final land preparation. Urea was top-dressed in three equal installments at 20, 40 and 60 days after transplanting (DAT), respectively. Forty days old seedlings were uprooted from the seedbed on January 14, 2014. Transplanting was done with one seedling in each hill at a spacing of $20 \times 15 \mathrm{~cm}$ on the same day. Intercultural operations such as irrigation, pest management and other necessary cultural operations were done accordingly. The crop under weed free treatment was kept weed free by continuing weeding operations every week.

Plant samplings were done at 15 days interval starting from 30 DAT until maturity. Data on different growth parameters, yield components and yield were collected. At each sampling data were recorded on the following parameters: Leaf area index (LAI) was measured from 30DAT at 15 days interval with Leaf area meter (Model AAM-7 Hayashi Denko Co. Tokyo, Japan). Leaf area index was then calculated by using the following formula as shown below:

LAI $=$ Leaf area for 5 hills $\left(\mathrm{cm}^{2}\right) /$ Land area occupied by 5 hills $\left(\mathrm{cm}^{2}\right)$

Crop growth rate was calculated using the following formula,

$\mathbf{C G R}=\mathbf{G A}^{-1}\{(\mathbf{W} 2-\mathrm{W} 1) /(\mathbf{T} 2-\mathbf{T} 1)\} \mathrm{g} \mathrm{m}^{-2} \mathrm{day}^{-1}$

$\mathrm{W} 1=$ Total dry weight at time $\mathrm{T} 1(\mathrm{~g}) \quad \mathrm{W} 2=$ Total dry weight at time $\mathrm{T} 2(\mathrm{~g})$

$\mathrm{T} 1=$ Initial time (day) $\quad \mathrm{T} 2=$ Final time $($ day $) \quad$ GA $=$ Ground area $\left(\mathrm{m}^{2}\right)$

Total nitrogen (TN) content was determined by micro-Kjeldahl method (Bremner and Mulvaney, 1982) using this formula,

$\% \mathrm{~N}$ of Grain or Straw $=(\mathrm{T}-\mathrm{B}) \times N \times 1.401 \times \mathrm{S}^{-1} \times 100$

$\mathrm{T}=$ Sample titration value $(\mathrm{mL})$ of standard $\mathrm{H}_{2} \mathrm{SO}_{4} \quad \mathrm{~S}=$ Weight of soil sample in $\mathrm{g}$ 
Effect of Nitrogen on Weed Infestation of Boro Rice Under Selected Herbicides

$\mathrm{B}=$ Blank titration value $(\mathrm{mL})$ of standard $\mathrm{H}_{2} \mathrm{SO}_{4} \quad \mathrm{~N}=$ Strength of $\mathrm{H}_{2} \mathrm{SO}_{4}$.

Nitrogen use efficiency (NUE) was calculated by following formula, (Olson and Swallow, 1984)

NUE $=($ NUna - NUno) $/$ NR

NUna $=$ Nitrogen uptake $\left(\mathrm{kg} \mathrm{ha}^{-1}\right)$ by grain with addition of nutrient

NUno $=$ Nitrogen uptake $\left(\mathrm{kg} \mathrm{ha}^{-1}\right)$ by grain without addition of nutrient

$\mathrm{NR}=$ Rate of added nutrient $\left(\mathrm{kg} \mathrm{ha}^{-1}\right)$.

Visual abundance of weeds was calculated through direct eye observation of standing weeds in the experimental plots at 60 DAT. The scores were used as $4=$ High; $3=$ Medium; $2=$ Low; $1=$ Very low/negligible.

Weed control efficiency was calculated with the following formula:

Weed control efficiency $($ WCE $)=\{($ DMC - DMT $) /$ DMC $\} \times 100$

$\mathrm{DMC}=$ Weed dry matter in unweeded treatment

DMT $=$ Weed dry matter in weed control treatment

Crop was harvested at well-matured stage on the date of 14 May 2014. At maturity, five plants were harvested from each plot to record data on yield components and the plants from an area of $2.4 \mathrm{~m}^{2}$ was harvested on grain and straw yields. The data were compiled and tabulated with the help of the computer package Statistix 10 and the means were separated through Least Significance Difference (LSD) test.

\section{Results and Discussion}

Considerable effects of dose of nitrogen and weed control treatments on weed infestation, weed control, crop growth and yield performance of Boro rice cv. BRRIdhan 28 were observed and discussed below:

\section{Weed species}

Nine different weed species belonging to five families of which seven annuals and two perennials were found Among the treatments, the most abundant weed species found was Scirpus maritimus L. contributing to $58 \%$ of total weed species being followed by Leersia hexandra sw. (12\%) and Paspalam distichum L. (9\%). Other important weeds were Fimbristylis miliaceae L. and Cyperus difformis $\mathrm{L}$.

The maximum average weed abundance (12\%) was found in $\mathrm{T} 4$ treatment receiving pre-emergence herbicide along with $151.8 \mathrm{~kg}$ of $\mathrm{N} \mathrm{ha}^{-1}$. In general, weed abundance increased with increase in $\mathrm{N}$ dose. It might be due to availability of nitrogen in soil that favoured luxuriant growth of weeds. However, post-emergence herbicide application (T6-T10) contributed to lesser abundance of weeds than those in pre-emergence one.

\section{Weed control efficiency (WCE)}

WCE varied significantly due to dose of nitrogen and herbicide application. WCE was inversely proportional to weed biomass, i.e. the lower the weed biomass, the higher the WCE. WCE increased steadily irrespective of nitrogen dose and herbicide application up to 60 DAT and then decreased (Fig. 1). Herbicides had significant effect on WCE. At 60 DAT, plots treated with post-emergence herbicide showed higher WCE than those with pre-emergence one. It might be due to that, the duration between application of post-emergence herbicide (15 DAT) and canopy closure by rice plants allowing lesser avenue for weeds to germinate and stand establishment, which did not occur in case of pre-emergence herbicide applied at 5 DAT. 
Morshed et al.

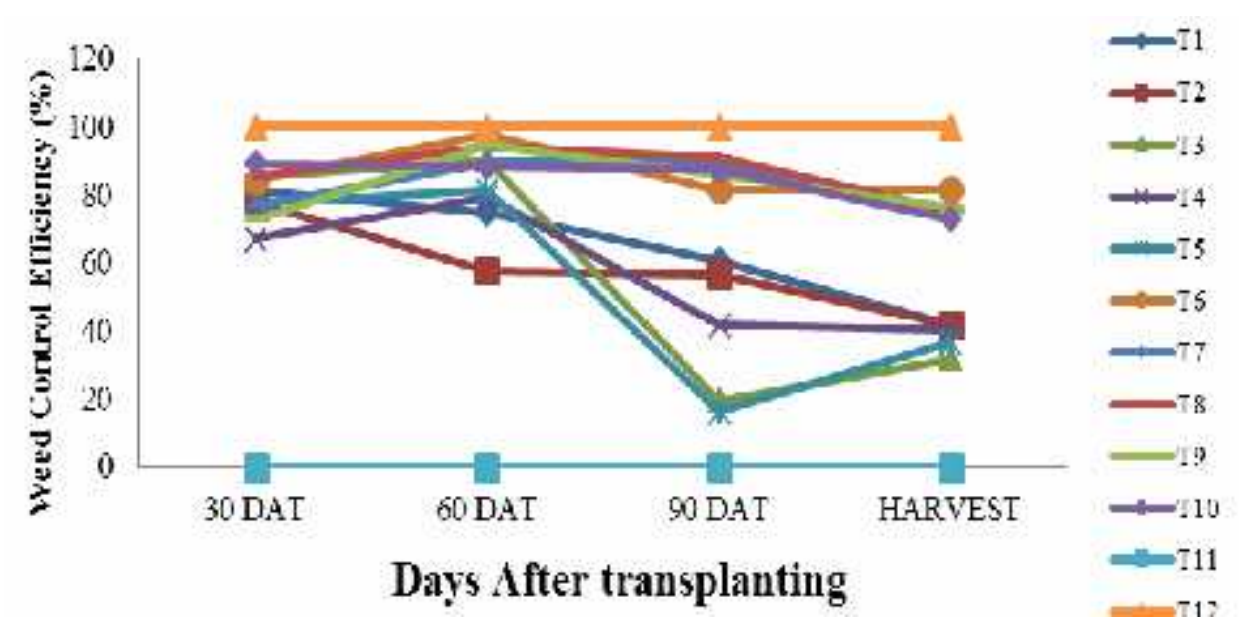

Fig. 1. Effect of $\mathrm{N}$ dose and herbicide on weed control efficiency in Boro rice field

\section{Crop growth and development}

Tiller dynamics: Tiller growth continued up to 75 DAT then decreased gradually in all the treatments probably due to mortality of ineffective tillers at later stages. At 75 DAT when tiller number reached its peak, the maximum number of tillers hill ${ }^{-1}$ (17.00) was found in T10 treatment receiving $202.4 \mathrm{~kg}$ of N $\mathrm{ha}^{-1}$ under coverage of post-emergence herbicide, while the least (10.20) in T1 treatment without $\mathrm{N}$ under pre-emergence herbicide (Fig. 2). Data indicated that, increasing $\mathrm{N}$-dose enhanced tiller production, particularly at 75 DAT (Table 1). However, the rate of increase was more prominent under post-emergence than under pre-emergence one. After 75 DAT and onwards, tiller number started to decline until maturity in all the treatments. It might be due to that tillers that were produced at later stages did not get much light for photosynthesis, which hampered their growth and development leading to mortality. At harvest tiller number was also the highest in T10 treatment, which was being followed by T9, T5 and T4 treatments in descending order (Table 1).

Tiller mortality rate was measured as the percent change of tiller number from the period of peak tiller growth to harvest (Table 1). The treatment $\mathrm{T} 7$ showed the maximum tiller mortality rate $(28.18 \%)$ which is followed by T10 (23.53\%) and T9 (18.54\%) under post emergence herbicide. Among the treatments under pre-emergence herbicide, T4 showed maximum tiller mortality rate (15.21\%) which is followed by $\mathrm{T} 5(11.93 \%)$ and $\mathrm{T} 1(11.77 \%)$, while the least $(5.89 \%)$ was found in $\mathrm{T} 3$ under pre emergence herbicide next to unweeded (Control) treatment. In general, treatments under pre emergence herbicides incurred lower mortality rate than that in treatments under post-emergence herbicides. 
Effect of Nitrogen on Weed Infestation of Boro Rice Under Selected Herbicides

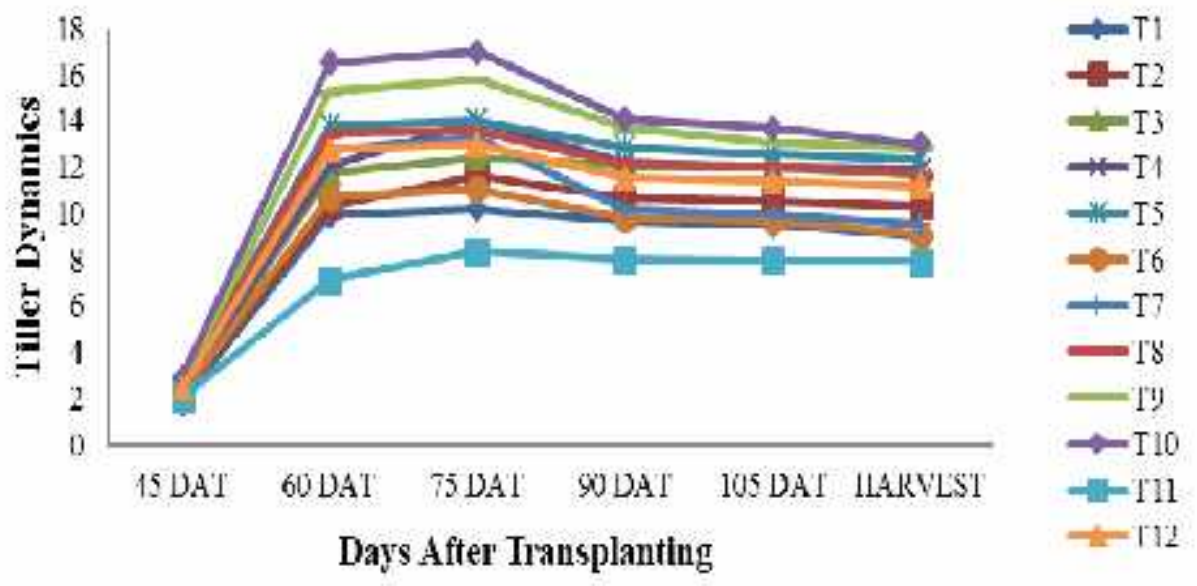

Fig. 2. Effect of $\mathrm{N}$ dose and herbicide on tiller dynamics in Boro rice

Table 1 . Tiller mortality rate as affected by different nitrogen doses under two selective herbicides

\begin{tabular}{c|c|c|c}
\hline \multirow{2}{*}{ Treatment } & \multicolumn{2}{|c|}{ Tiller hill $^{-1}$} & \multirow{2}{*}{$\begin{array}{c}\text { \% Change } \\
\text { (75 DAT to Harvest) }\end{array}$} \\
\cline { 2 - 3 } & 75 DAT & Harvest & -11.77 \\
T1(H1N1) & 10.2 & 9 & -10.95 \\
T2(H1N2) & 11.6 & 10.33 & -5.89 \\
T3(H1N3) & 12.4 & 11.67 & -15.21 \\
T4(H1N4) & 14 & 11.87 & -11.93 \\
T5(H1N5) & 14 & 12.33 & -18.07 \\
T6(H2N1) & 11.07 & 9.07 & -28.18 \\
T7(H2N2) & 13.27 & 9.53 & -13.75 \\
T8(H2N3) & 13.53 & 11.67 & -18.54 \\
T9(H2N4) & 15.8 & 12.87 & -23.53 \\
T10(H2N5) & 17 & 13 & -4.80 \\
T11(Cont) & 8.33 & 7.93 & -13.85 \\
T12(WF) & 13 & 11.2 & \\
\hline CV $(\%)$ & 4.15 & 5.4 & \\
LSD 0.05 & 0.90 & 2.55 & \\
\hline
\end{tabular}

Leaf area index (LAI): LAI sharply increased up to 75 DAT, and then declined steadily irrespective of treatment. Nitrogen doses had significant effect on LAI (Fig. 3). Among the treatments, T10 (H2N5) contributed to the highest LAI whereas control (T11) treatment showed the lowest LAI throughout the sampling periods. At 75 DAT, , the maximum LAI (3.887) was found in T10 treatment (202.4 $\mathrm{kg} \mathrm{N} \mathrm{ha}^{-1}$ ) under coverage of post emergence herbicide. Other than control treatment, the lowest LAI (1.828) was noticed in T1 treatment during the same period. Data indicated that treatments receiving higher doses of $\mathrm{N}$ particularly under post emergence herbicide contributed to higher LAI. This result was in accordance with the earlier findings of Rahman et al. (2007). 
Morshed et al.

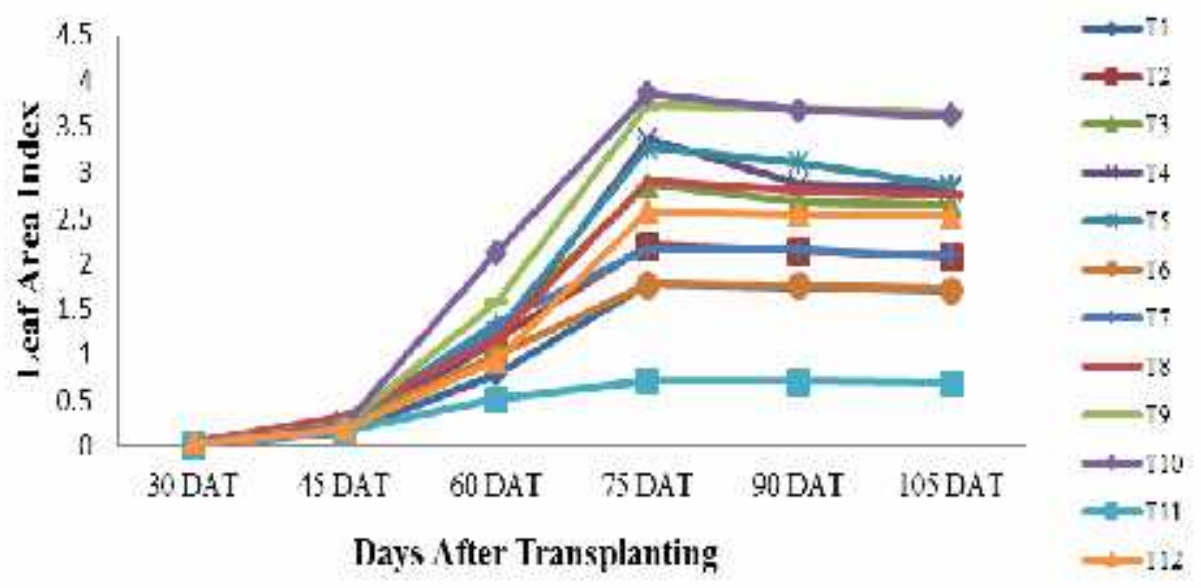

Fig. 3. Effect of $\mathrm{N}$ dose and herbicide on leaf area index in Boro rice

Total dry matter (TDM) production

TDM production was significantly influenced by nitrogen dose associated with selected herbicides (Fig. 4). At the harvest, T10 produced the maximum TDM of $1568.6 \mathrm{~g} \mathrm{~m}^{-2}$ which was followed by $1490.2 \mathrm{~g} \mathrm{~m}^{-2}$ in T9 treatment and $1335.3 \mathrm{~g} \mathrm{~m}^{-2}$ in T12 treatment (Weed free). Similar trend was found in case of pre-emergence herbicide treated plots. It might be due to that higher nitrogen dose enhanced higher vegetative growth and carbohydrate assimilation in the crop plants. Azarpour et al. (2014), Azarpour et al. (2011) and Bannayan et al. (2005) reported similar results about changes of dry weight under nitrogen fertilizer application.

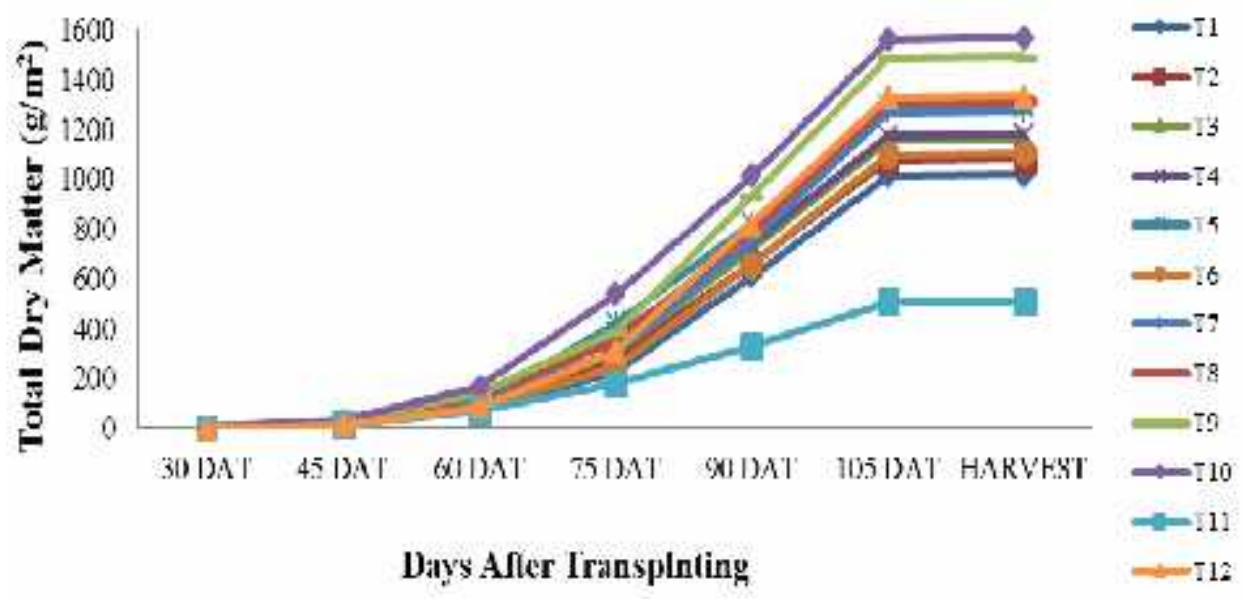

Fig. 4. Effect of $\mathrm{N}$ dose and herbicide on total dry matter production in Boro rice

Apart from control treatment, the lowest TDM $\left(1018 \mathrm{~g} \mathrm{~m}^{-2}\right)$ was produced in T1 treatment under preemergence herbicide. This reduction in TDM might be due to lower weed control efficiency in this treatment increased nutrient competition with rice crop and lower nitrogen availability for crop growth.

\section{Yield performance of Boro rice}

The maximum grain yield of $6.46 \mathrm{t} \mathrm{ha}^{-1}$ was recorded in T10 treatment which was followed by $6.41 \mathrm{t}$ $\mathrm{ha}^{-1}$ in T9 and $6.34 \mathrm{t} \mathrm{ha}^{-1}$ in T5 (Table 2). The highest grain yield in T10 treatment was the cumulative effect of the highest tiller hill ${ }^{-1}(13.00)$, panicle hill ${ }^{-1}(10.60)$ and number of filled grains panicle ${ }^{-1}$ 
Effect of Nitrogen on Weed Infestation of Boro Rice Under Selected Herbicides

(125.20). Data indicated that post emergence herbicide treated plots performed better in terms of yield contributing characters as well as grain yield compared to those under pre-emergence herbicide treatment (Table 2; Table 3). It might be due to that, rice plants under coverage of post-emergence herbicide responded well to increasing doses of $\mathrm{N}$, thus resulting higher tillering, higher panicle growth as well as higher number of fertile grains panicle. The positive relationship between tiller and panicle production was also stronger under post-emergence herbicide than in pre-emergence one (Fig. 5). However, the benefits were more prominent under post-emergence herbicide than under preemergence one (Table 2; Table 3). Particularly, grain filling process was more favourably influenced by N-dose when it occurred under post-emergence herbicide coverage (Fig. 6).

Table 2. Effect of nitrogen dose on yield performance in Boro rice under two selective herbicides

\begin{tabular}{|c|c|c|c|c|c|c|c|c|}
\hline $\begin{array}{l}\text { Treatme } \\
\mathrm{nt}\end{array}$ & $\begin{array}{l}\text { Tillers/ } \\
\text { hill }\end{array}$ & $\begin{array}{c}\text { Panicles/ } \\
\text { hill }\end{array}$ & $\begin{array}{l}\text { Filled } \\
\text { grains/ } \\
\text { panicle }\end{array}$ & $\begin{array}{c}\text { Unfilled } \\
\text { grain / } \\
\text { panicle }\end{array}$ & $\begin{array}{l}1000 \text { - grain } \\
\text { weight ( } \mathrm{g})\end{array}$ & $\begin{array}{l}\text { Grain } \\
\text { Yield } \\
\left(\mathrm{t} \mathrm{ha}^{-1}\right)\end{array}$ & $\begin{array}{c}\text { Straw } \\
\text { yield } \\
\left(\mathrm{t} \mathrm{ha}^{-1}\right)\end{array}$ & $\mathrm{HI}$ \\
\hline $\begin{array}{l}\text { T1 } \\
\text { (H1N1) }\end{array}$ & $9.00 \mathrm{f}$ & $6.73 \mathrm{e}$ & $100.73 \mathrm{~d}$ & $3.77 \mathrm{~b}$ & $22.53 \mathrm{c}$ & $3.03 \mathrm{~d}$ & $3.54 \mathrm{e}$ & $0.47 \mathrm{a}$ \\
\hline $\begin{array}{l}\mathrm{T} 2 \\
\text { (H1N2) }\end{array}$ & $10.33 \mathrm{de}$ & $7.27 \mathrm{de}$ & $116.27 \mathrm{c}$ & $4.17 \mathrm{~b}$ & $23.55 \mathrm{ab}$ & $5.30 \mathrm{~b}$ & $5.53 \mathrm{~cd}$ & $0.49 \mathrm{a}$ \\
\hline $\begin{array}{l}\text { T3 } \\
\text { (H1N3) }\end{array}$ & $11.67 \mathrm{bc}$ & $8.00 \mathrm{~cd}$ & $116.77 \mathrm{bc}$ & $5.10 \mathrm{a}$ & $23.61 \mathrm{ab}$ & $5.87 \mathrm{ab}$ & $6.10 \mathrm{bc}$ & $0.49 \mathrm{a}$ \\
\hline $\begin{array}{l}\text { T4 } \\
\text { (H1N4) }\end{array}$ & $11.87 \mathrm{bc}$ & $8.80 \mathrm{bc}$ & $122.40 \mathrm{abc}$ & $5.17 \mathrm{a}$ & $23.08 \mathrm{abc}$ & $6.10 \mathrm{a}$ & $6.37 \mathrm{bc}$ & $0.49 \mathrm{a}$ \\
\hline $\begin{array}{l}\text { T5 } \\
\text { (H1N5) }\end{array}$ & $12.33 \mathrm{ab}$ & $10.33 \mathrm{a}$ & $124.37 \mathrm{a}$ & $5.30 \mathrm{a}$ & $23.85 \mathrm{a}$ & $6.34 \mathrm{a}$ & $7.60 \mathrm{a}$ & $0.46 \mathrm{ab}$ \\
\hline $\begin{array}{l}\text { T6 } \\
\text { (H2N1) }\end{array}$ & $9.07 \mathrm{f}$ & $7.07 \mathrm{de}$ & $121.27 \mathrm{abc}$ & $3.47 \mathrm{bc}$ & $22.58 \mathrm{c}$ & $3.19 \mathrm{~d}$ & $4.47 \mathrm{de}$ & $0.42 \mathrm{~b}$ \\
\hline $\begin{array}{l}\text { T7 } \\
\text { (H2N2) }\end{array}$ & 9.53 ef & $7.27 \mathrm{de}$ & $122.17 \mathrm{abc}$ & $4.17 \mathrm{~b}$ & $22.80 \mathrm{bc}$ & $5.35 \mathrm{~b}$ & $5.57 \mathrm{~cd}$ & $0.49 \mathrm{a}$ \\
\hline $\begin{array}{l}\mathrm{T} 8 \\
(\mathrm{H} 2 \mathrm{~N} 3)\end{array}$ & $11.67 \mathrm{bc}$ & $9.60 \mathrm{ab}$ & $123.57 \mathrm{abc}$ & $5.23 \mathrm{a}$ & $23.52 \mathrm{ab}$ & $5.82 \mathrm{ab}$ & $5.85 \mathrm{bc}$ & $0.50 \mathrm{a}$ \\
\hline $\begin{array}{l}\text { T9 } \\
(\mathrm{H} 2 \mathrm{~N} 4)\end{array}$ & $12.87 \mathrm{a}$ & $10.07 \mathrm{a}$ & $123.67 \mathrm{ab}$ & $5.20 \mathrm{a}$ & $23.66 \mathrm{ab}$ & $6.41 \mathrm{a}$ & $6.79 a b$ & $0.49 \mathrm{a}$ \\
\hline $\begin{array}{l}\text { T10 } \\
\text { (H2N5) }\end{array}$ & $13.00 \mathrm{a}$ & $10.60 \mathrm{a}$ & $125.20 \mathrm{a}$ & $5.67 \mathrm{a}$ & $23.83 \mathrm{a}$ & $6.46 \mathrm{a}$ & $6.91 \mathrm{ab}$ & $0.48 \mathrm{a}$ \\
\hline $\begin{array}{l}\text { T11 } \\
\text { (Cont) }\end{array}$ & $7.93 \mathrm{~g}$ & $7.33 \mathrm{de}$ & $75.70 \mathrm{e}$ & $2.87 \mathrm{c}$ & $23.56 \mathrm{ab}$ & $1.78 \mathrm{e}$ & $2.06 \mathrm{f}$ & $0.47 \mathrm{a}$ \\
\hline $\begin{array}{l}\text { T12 } \\
\text { (WF) }\end{array}$ & $11.20 \mathrm{~cd}$ & $9.67 \mathrm{ab}$ & $120.17 \mathrm{abc}$ & $4.17 \mathrm{~b}$ & $23.26 \mathrm{abc}$ & $4.52 \mathrm{c}$ & $4.63 \mathrm{de}$ & $0.49 \mathrm{a}$ \\
\hline CV (\%) & 5.40 & 8.27 & 3.73 & 9.16 & 2.36 & 8.64 & 7.29 & 5.74 \\
\hline LSD & 0.99 & 1.19 & 7.32 & 0.70 & 0.93 & 0.73 & 1.21 & 0.046 \\
\hline$(0.05)$ & & & & & & & & \\
\hline
\end{tabular}

Table 3. Changes in grain yield in relation to weed free and control plots.

\begin{tabular}{c|c|c|c|c}
\hline Treatment & $\begin{array}{c}\text { Grain yield } \\
\left(\mathrm{t} \mathrm{ha}^{-1}\right)\end{array}$ & $\begin{array}{c}\text { Average grain yield } \\
\left(\mathrm{t} \mathrm{ha}^{-1}\right)\end{array}$ & $\begin{array}{c}\text { \% Change from } \\
\text { Weed free }\end{array}$ & $\begin{array}{c}\% \text { Change from } \\
\text { control }\end{array}$ \\
\hline
\end{tabular}


Morshed et al.

\begin{tabular}{ccccc}
\hline T1(H1N1) & 3.03 & & -32.96 & 70.22 \\
T2(H1N2) & 5.3 & 5.328 & 17.26 & 197.75 \\
T3(H1N3) & 5.87 & & 29.87 & 229.78 \\
T4(H1N4) & 6.1 & 34.96 & 242.70 \\
T5(H1N5) & 6.34 & & 40.27 & 256.18 \\
\hline T6(H2N1) & 3.19 & & -29.42 & 79.21 \\
T7(H2N2) & 5.35 & 5.446 & 18.36 & 200.56 \\
T8(H2N3) & 5.82 & & 28.76 & 226.97 \\
T9(H2N4) & 6.41 & & 41.81 & 260.11 \\
T10(H2N5) & 6.46 & - & 42.92 & 262.92 \\
\hline T11(Cont) & 1.78 & - & -60.62 & - \\
T12(WF) & 4.52 & & - & 153.93 \\
\hline
\end{tabular}
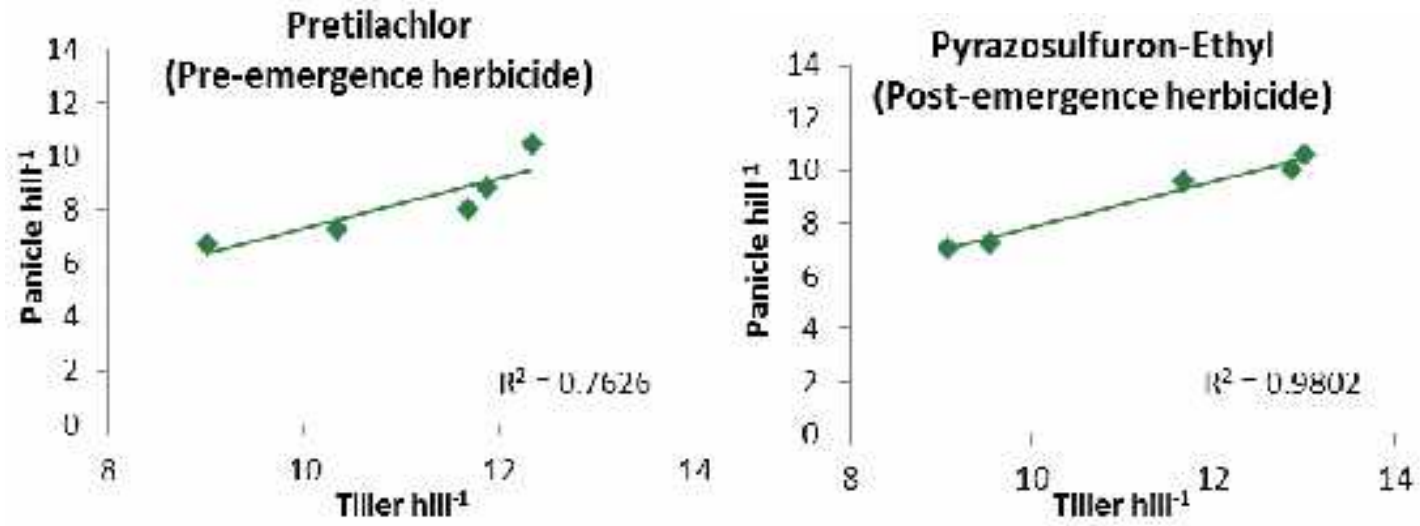

Fig. 5. Relationship between total tiller production and panicle formation efficiency of Boro rice under two selected herbicides

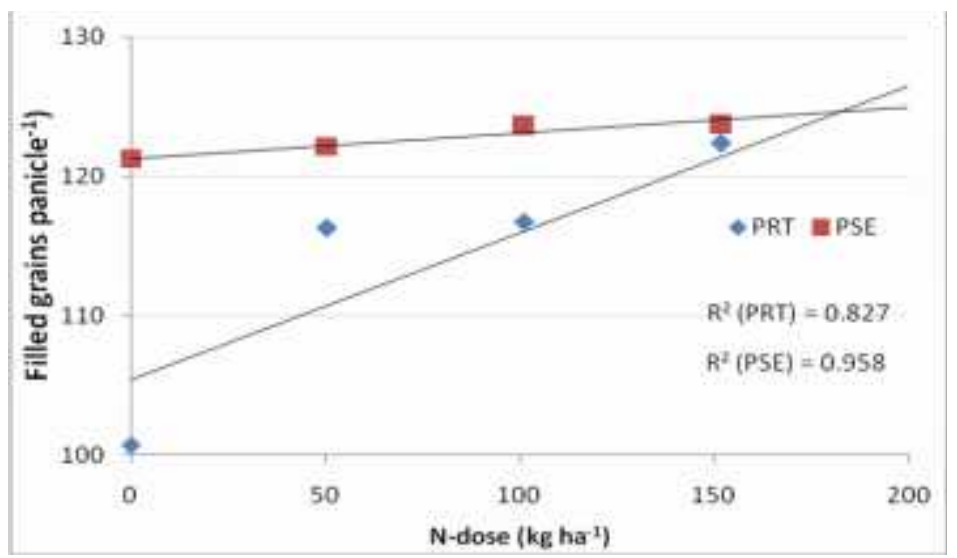

Fig. 6. Relationship between $\mathrm{N}$ dose and filled grains

\section{Nitrogen use efficiency}

The highest grain-N content (1.40\%) was recorded in T10 treatment receiving $202.4 \mathrm{~kg} \mathrm{~N}^{-1}$, while the least $(0.77 \%)$ was found in $\mathrm{T} 1$ treatment receiving no $\mathrm{N}$. Data revealed that, with the increase in applied $\mathrm{N}, \mathrm{N}$-uptake by rice plants also increased. The relationship between $\mathrm{N}$ dose and grain- $\mathrm{N}$ 
Effect of Nitrogen on Weed Infestation of Boro Rice Under Selected Herbicides

content was stronger in post emergence herbicide than that in pre-emergence herbicide in case of grain yield of rice (Fig. 7). It might be due to that, under post emergence herbicide coverage translocation of photosynthate in grain and $\mathrm{N}$-utilization were higher as driven by stronger vegetative growth of rice plants during late vegetative and grain filling stages with higher $\mathrm{N}$ dose coupled with lesser weed infestation. Data indicated that, $\mathrm{N}$-use efficiency was higher when $\mathrm{N}$-dose was lower (Table 4). It might be due to that, under higher $\mathrm{N}$-dose, leaching, volatilization, uptake by weed plants and other losses were higher, thus resulting lesser availability of applied $\mathrm{N}$ to the crop plants.

Table 4. Effect of $\mathrm{N}$ dose and herbicide on Nitrogen use efficiency of Boro rice

\begin{tabular}{ccccccc}
\hline Treatment & $\begin{array}{c}\text { Urea } \\
\mathrm{kg} \mathrm{ha}^{-1}\end{array}$ & $\begin{array}{c}\text { Applied N } \\
\mathrm{kg} \mathrm{ha}^{-1}\end{array}$ & $\begin{array}{c}\text { grain yield } \\
\left(\mathrm{t} \mathrm{ha}^{-1}\right)\end{array}$ & $\mathrm{N} \%$ grain & $\begin{array}{c}\mathrm{N} \text { uptake } \\
\left(\mathrm{kg} \mathrm{ha}^{-1}\right)\end{array}$ & NUE \\
\hline T1 (H1N1) & 0 & 0 & 3.03 & 0.77 & 23.41 & - \\
T2 (H1N2) & 110 & 50.6 & 5.30 & 0.89 & 46.96 & 0.47 \\
T3 (H1N3) & 220 & 101.2 & 5.87 & 1.21 & 71.25 & 0.47 \\
T4 (H1N4) & 330 & 151.8 & 6.10 & 1.31 & 79.71 & 0.37 \\
T5 (H1N5) & 440 & 202.4 & 6.34 & 1.35 & 85.78 & 0.31 \\
T6 (H2N1) & 0 & 0 & 3.19 & 0.78 & 24.89 & - \\
T7 (H2N2) & 110 & 50.6 & 5.35 & 0.93 & 49.89 & 0.49 \\
T8 (H2N3) & 220 & 101.2 & 5.82 & 1.07 & 62.46 & 0.37 \\
T9 (H2N4) & 330 & 151.8 & 6.41 & 1.21 & 77.82 & 0.35 \\
T10 (H2N5) & 440 & 202.4 & 6.46 & 1.40 & 90.43 & 0.32 \\
T11 (Cont) & 0 & 0 & 1.78 & 0.84 & 14.94 & - \\
T12 (WF) & 220 & 101.2 & 4.52 & 0.98 & 44.30 & 0.29 \\
\hline
\end{tabular}

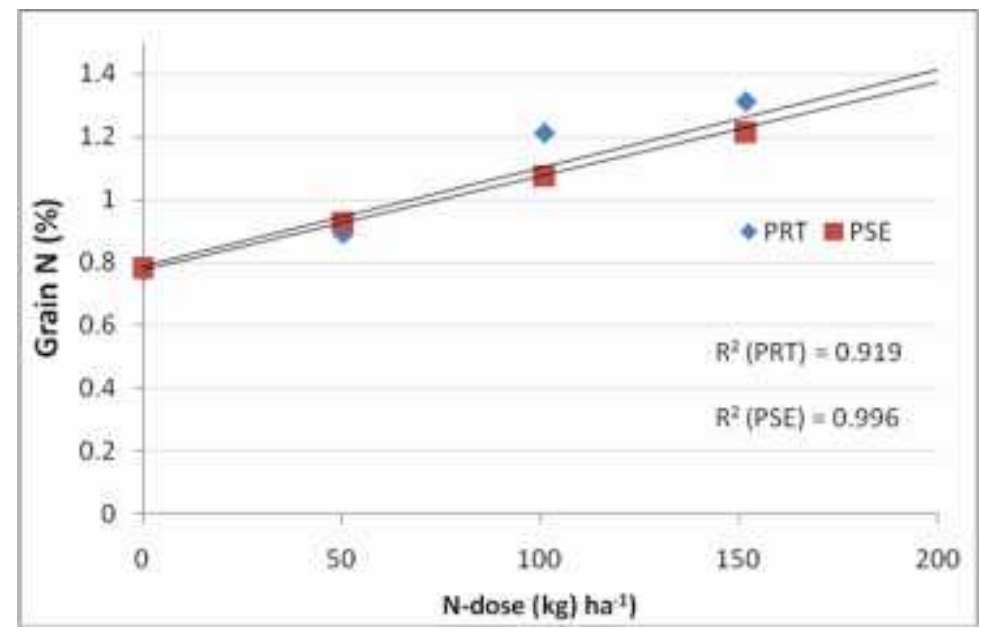

Fig. 7. Relationship between $\mathrm{N}$ dose and grain $\mathrm{N}$-content of Boro rice as affected by herbicide Benefit cost ratio (BCR) was varied from 0.50 to 1.60 among the treatments. In general, treatments with higher nitrogen dose, showed higher BCR irrespective of herbicide. Again, treatments under post emergence herbicide showed higher BCR than that in treatments under pre-emergence herbicide. The highest BCR (1.60) was found in T9 treatment receiving $151.8 \mathrm{~kg} \mathrm{~N} \mathrm{ha}^{-1}$ under post emergence herbicide, which was followed by T10, T5 and T4 treatments.

Table 5. Gross return, Cultivation cost, net return and benefit cost ratio of different treatment 
Morshed et al.

\begin{tabular}{|c|c|c|c|c|c|c|c|c|c|}
\hline \multirow[t]{2}{*}{ Treatment } & \multicolumn{2}{|c|}{ Yield } & \multirow{2}{*}{$\begin{array}{c}\text { Gross } \\
\text { return } \\
(\mathrm{Tk} .)\end{array}$} & \multicolumn{4}{|c|}{ Cultivation cost } & \multirow{2}{*}{$\begin{array}{c}\text { Net } \\
\text { return } \\
(\mathrm{Tk} .)\end{array}$} & \multirow{2}{*}{$\begin{array}{c}\text { Benefit } \\
\text { Cost } \\
\text { Ratio }\end{array}$} \\
\hline & $\begin{array}{l}\text { Grain } \\
\left(\mathrm{t} \mathrm{ha}^{-1}\right)\end{array}$ & $\begin{array}{l}\text { Straw } \\
\left(\mathrm{t} \mathrm{ha}^{-1}\right)\end{array}$ & & $\begin{array}{l}\text { Other cost } \\
\text { (except } \\
\text { weeding } \\
\text { and Urea) }\end{array}$ & $\begin{array}{c}\text { Urea } \\
\text { fertilizer } \\
\text { cost (Tk.) }\end{array}$ & $\begin{array}{c}\text { Herbicide } \\
\text { cost } \\
\text { (Tk.) }\end{array}$ & $\begin{array}{l}\text { Total } \\
\text { cost } \\
(\mathrm{Tk} .)\end{array}$ & & \\
\hline T1 (H1N1) & 3.03 & 3.54 & 67638 & 79934 & 0 & 2190 & 82124 & -14486 & 0.82 \\
\hline $\mathrm{T} 2$ (H1N2) & 5.30 & 5.53 & 116963 & 79934 & 3370 & 2190 & 85494 & 31469 & 1.37 \\
\hline T3 (H1N3) & 5.87 & 6.10 & 129643 & 79934 & 5570 & 2190 & 87694 & 41949 & 1.48 \\
\hline T4 (H1N4) & 6.10 & 6.37 & 134739 & 79934 & 7770 & 2190 & 89894 & 44845 & 1.50 \\
\hline T5 (H1N5) & 6.34 & 7.60 & 141971 & 79934 & 9970 & 2190 & 92094 & 49876 & 1.54 \\
\hline T6 (H2N1) & 3.19 & 4.47 & 72762 & 79934 & 0 & 990 & 80924 & -8162 & 0.90 \\
\hline $\mathrm{T} 7$ (H2N2) & 5.35 & 5.57 & 118047 & 79934 & 3370 & 990 & 84294 & 33753 & 1.40 \\
\hline T8 (H2N3) & 5.82 & 5.85 & 128089 & 79934 & 5570 & 990 & 86494 & 41595 & 1.48 \\
\hline T9 (H2N4) & 6.41 & 6.79 & 141861 & 79934 & 7770 & 990 & 88694 & 53167 & 1.60 \\
\hline T10 (H2N5) & 6.46 & 6.91 & 143006 & 79934 & 9970 & 990 & 90894 & 52112 & 1.57 \\
\hline T11 (Cont) & 1.78 & 2.06 & 39695 & 79934 & 0 & 0 & 79934 & -40239 & 0.50 \\
\hline $\mathrm{T} 12(\mathrm{WF})$ & 4.52 & 4.63 & 99670 & 79934 & 5570 & 10140 & 95644 & 4026 & 1.04 \\
\hline
\end{tabular}

Note: Price of grain and straw were Tk. 20.00 and Tk. 2.00, respectively

\section{Conclusion}

Treatment receiving $202.4 \mathrm{~kg} \mathrm{~N}$ ha $^{-1}$ under post-emergence herbicide contributed to the highest grain yield and grain nitrogen content. But, the highest benefit cost ratio was obtained when $\mathrm{N}$ was applied @ $151.8 \mathrm{~kg} \mathrm{ha}^{-1}$ of the recommended dose under post emergence herbicide application.

\section{References}

Azarpour, E., M. Moraditochaee and H. R. Bozorgi. 2014. Effect of nitrogen fertilizer management on growth analysis of rice cultivars. Int. J. Biosci. Vol. 4, No. 5, p. 35-47

Azarpour, E., M. K. Motamed, M. Moraditochaee and H. R. Bozorgi. 2011. Effect of nitrogen fertilizer and nitroxin biofertilizer management on growth analysis and yield of rice cultivars (Iran). World Applied Sciences Journal 14(2), 193-198.

Bannayan, M, K. Kobayashi, H. Y. Kim, M. Lieffering, M. Okada and S. Miura. 2005. Modeling the interactive effects of atmospheric $\mathrm{CO}_{2}$ and $\mathrm{N}$ on rice growth and yield. Field Crops Research: 93, 237-251. http://dx.doi.org/10.1016/j.fcr.2004.10.003

Bremner, J. M. and C. S., Mulvaney. 1982. Nitrogen-Total. In: A.L. page, R.H. Miller (Eds). Methods of Soil Analysis. Part 2. $2^{\text {nd }}$ ed. Agron. Monogr. 9. ASA and SSSA, Madison, WI. pp.595-624.

BRRI (Bangladesh Rice Research Institute). 1999. Adhunik Dhaner Chash (in bengali). Bangladesh Rice Research Institute, Joydebpur, Gazipur, pp:12

BRRI (Bangladesh Rice Research Institute). 2011. Adhunik Dhaner Chash (in bengali). Bangladesh Rice Research Institute, Joydebpur, Gazipur, pp: 5.

BRRI (Bangladesh Rice Research Institute). 2009. BRRI Annual Internal Review 2007-2008. Soil Science Division. Bangladesh Rice Research Institute, Gazipur-1701. 
Effect of Nitrogen on Weed Infestation of Boro Rice Under Selected Herbicides

Chauhan B, S. and S. B. Abugho, 2013. Growth and Echinochloa glabresces in response to cultivar and density. Journal of crop improvement. 27(4): 391-405

Dastan, S., M. Siavoshi, D. Zakavi, A. Ghanbaria-malidarreh, R. Yadi, E. Ghorbannia Delavar, and A. R. Nasiri. 2012. Application of nitrogen and silicon rates on morphological and chemical lodging related characteristics in rice (Oryza sativa L.) north of Iran. Journal of Agricultural Science, 4(6).

Mamun, M. A. A., R. Sultana, M. A. Sidique, M. S. Jahan and S. Pramanik, 2011. Efficacy of different commercial product Oxadiazon and Pyrazosulfuran-Ethyl on rice and Associate weeds in dry season rice cultivation. World Journal of Agricultural Sciences 7(3): 341-346, 2011

Nyarko, A. k. and S. K. De Datta, 1993. Effect of light and nitrogen and their interaction on the dynamics of rice-weed competition. Weed Res. 33:1-8.

Olson, R.V., and C.W. Swallow. 1984. Fate of labeled nitrogen fertilizer applied to winter wheat for five years. Soil Sci. Soc. Am. J. 48:583-586.

Rahman, M. H., M. H. Ali, M. M. Ali and M. M. Khatun. 2007. Effect of Different Level of Nitrogen on Growth and Yield of Transplant Aman Rice cv. BRRIdhan32. Int. J. Sustain. Crop Prod. 2(1): 28-34. 